\title{
Training Programme on Major Tectonics and Lithounits in the Indus and Shyok Suture Zones of Ladakh Himalaya - M. Ram Mohan, (NGRI-CSIR, Hyderabad.Email: rammohan@ngri.res.in) and Sita Bora (Kumaun University, Nainital; Email: sitabora@yahoo.com)
}

DST-sponsored advanced field training program on "Major tectonics and lithounits in the Indus and Shyok suture zones of Ladakh Himalaya" was convened by Prof. Santosh Kumar of Kumaun University, Nainital, between $1^{\text {st }}$ and $15^{\text {th }}$ August 2011. Seventeen researchers and young scientists representing various universities, research institutes and from the Ministry of Earth Sciences, New Delhi, participated in the training programme. Major aims of the programme were to provide an understanding on the basic issues of mafic-felsic magmatism, metamorphism and tectonism, associated with Indus-Shyok suture zones through systematic field study, along and across the central-eastern part of the Ladakh Himalaya. Suture zones generally represent collage of two continental blocks, along which the oceanic lithosphere might have got obducted. Along the planned geotraverses, outcrop features provided an ample opportunity to the participants and to enhance their field-based observational skills. The mentors for this program were Dr. Hakim Rai and Dr. A.K. Dubey, WIHG, Dehradun; Dr. Raymond Duraiswamy, Pune University, apart from Prof. Santosh Kumar, who together demonstrated and explained thoroughly the field features offering excellent opportunity for lengthy discussion and interaction with the participating scientists at outcrops.

The training program was formally inaugurated by Prof. V.P.S. Arora, the Honorable Vice-Chancellor of Kumaun University on the evening of $1^{\text {st }}$ August 2011 at Leh. He emphasized the need for more detailed and integrated field geological studies in such complex terrains. Prof. Talat Ahmad, the Honorable Vice-Chancellor of Kashmir University, shared his expertise on Himalayan evolutionary history. He outlined the similarities and contrast between the Shyok and Indus suture zones based on geochemical and geochronological investigations on magmatic and metamorphic lithounits of Pangong Metamorphic Complex in Tangtse shear zone.
First two days of the fieldwork was devoted for the investigation of various types of microgranular enclaves, syn-to post-plutonic mafic dykes, dioritic mafic and felsic lithounits that are exposed in the central part (Ganglas, Sobu, and surrounding areas of Leh) of Ladakh batholith for understanding the physics and dynamics of the magma chamber processes. In various exposures, identified the enclave swarms, brecciated magmatic enclaves and differentiated them from enclaves as solid fragments. Prof. Santosh Kumar demonstrated on the outcrops about the concepts and mechanism of magma mixing, mingling, and magma flowage at outcrop scale with relation to the regional tectonics and dynamics of multiple mafic-felsic pulses forming the bulk of Ladakh batholith. Some dykes of the tourmaline bearing pegmatites has also been found intruding into the Sobu diorite-granodiorite complex, suggesting the evolution of late stage hydrothermal system. In and around Sobu, large bodies of forerunner diorite mafic magma were followed by the emplacement of granodiorite masses, evident by large-scale colour contrast.

In the traverse along the Tangtse mylonite zone, Dr. A.K. Dubey explained the shear sense features and related fabrics, apart from visualizing the effects of deformation. The cross-section of the Tangtse Metamorphic Complex enabled to elucidate the syn-deformational partial melting processes at outcrop and at larger scale, similar to those commonly observed in Tonalite-Trondhjemite-Granodiorite (TTG) rocks of Archean cratons. In this section, concordant and discordant leucocratic melts along with restitic materials exhibited various stages of deformational features. Concept of insitu granite melt generation, its separation from source region and ascent in the network style were lucidly explained and discussed. Dr. Hakim Rai gave an overview on the regional setting of Tangtse Metamorphic Complex, Karakoram batholith and Muglib pluton and discussed the structural, lithotectonic relationship and evolutionary styles. An outcrop section of Dabruk granite was studied in the framework of crustal melting and differentiation processes. Leucocratic melt generation and its passage through structural conduits was identical to those observed in Tangtse Shear Zone, except that the degree of melt generation was substantially lower than the observed melt volume at Tangtse region. Dr. R.A. Duraiswami elucidated the significance of ophiolites in a subduction zone framework, through the examination of complete cross-section of well-preserved Nidar ophiolite sequence. Eclogite and amphibolite bearing Puga gneisses of TsoMorari crystallines and the occurrence of hot springs, sulphur and borax deposits are some of the interesting features observed within the Puga gneissic terrain. A traverse through Khardung-La volcanics helped to understand the structural and physical features of passive to forceful volcanic eruptions. Interesting field features of subvolcanic intrusion of Tirit and other smaller granitic bodies and parts of Karakoram batholith associated with dykes and migmatites were also observed along the Nubra valley. Along Leh-Karu-Upshi-HimyaLitse, we observed tourmaline bearing mineralized (muscovite, beryl and bornite) and unmineralized pegmatite veins of various dimensions which intruded the Ladakh granites of leucocratic nature.

This training program provided an opportunity for greater geoscientific interactions between the trainees and mentors. The participation of Dr. Umesh Sharma from DST for most part of the field program helped the participants to know more about DST programs for young researchers such as FASTTRACK and Inspire. DST is thanked for sponsoring field oriented advanced training program.

Special mention must be made of the help and logistic support provided by Dr. C. P. Dorjey. The participants extend thanks to the mentors and deeply acknowledge the financial grant of DST. 